\title{
A MOSAIC DISEASE OF COWPEA (VIGNA SINENSIS SAVI) IN PUERTO RICO
}

In November 1962 some plants of cowpea, Vigna sinensis Savi, grown at the Gurabo Substation, exhibited mosaic symptoms. Samples from affected plants were collected and brought to the laboratory where the virus was easily transferred to healthy cowpea plants by rubbing the sap from infected plants on the leaves with the aid of carborundum.

The symptoms of the disease in the field and on the inoculated plants are the following: Vein-clearing of new leaves, followed by a generalized mottling of all leaves. The leaves are malformed and reduced in size. At a later stage of development the disease becomes severe and the leaves show chlorosis with small green areas dispersed over their surface. Diseased plants bear few and smaller pods than healthy ones.

The virus has a dilution end-point in crude sap of $1: 10,000$. It is inactivated at $60^{\circ} \mathrm{C}$. for 10 minutes, and loses its infectivity at room temperature $\left(28-30^{\circ} \mathrm{C}\right.$.) after 48 hours. This virus is not transmitted through the seed.

Besides cowpea, the virus infects pigeonpea, Cajan Cajan (L), Canavalia ensiformis (DC), Desmodium distortium (Aubl.) and Desmodium gyroides (DC). The following plants were inoculated but did not show symptoms: Lycopersicon esculentum (L) Karst var. Marglobe, Nicotiana glutinosa (L), Nicotiana tabacum (L) var. Virginia, Datura stramonium (L), Cucumis sativus (L) var. Black Diamond, Capsicum frutescens (L) var. California Wonder, Capsicum frutescens (L) var. Large Bell Hot, Capsicum frutescens (L) var. Hope, Gomphrena globosa (L), Vicia faba (L) var. Fordhook, Stizolobium Deeringianum (Bort.), Phaseolus vulgaris (L) vars. Scotia and Bonita, Ipomea purpurea (Lam.) var. Crimson Rambler, Crotalaria anagyroides (HBK), Cassia tora (L) and Zinnia elegans (Jacq.) var. Golden Gem.

Cook $^{1}$ reported a mosaic disease of cowpeas in Puerto Rico but he offered no data as to transmissibility, physical properties, or host range of the virus. According to the exhaustive studies of Anderson ${ }^{2}$ in relation to the viruses that attack the cowpea, Crotalaria, and other leguminous plants in Florida, he was able to distinguish seven groups of viruses most of them capable of infecting cowpea.

To which one of these group or groups the cowpea virus found in Puerto Rico belongs, which insect transmits it, etc., is under study at present.

José Adsuar

Department of Plant Pathology and Botany

${ }^{1}$ Cook, M. T., Enfermedades de las Plantas Económicas de las Antillas, Monografía de la Universidad de P.R., Serie B, No. 4, p. 478, 1939.

${ }^{2}$ Anderson, C. W., Vigna and Crotalaria viruses in Florida, Plant Dis. Rptr. 39 $346-48 ; 349-53 ; 254-7,1955$. 